\title{
Correction to: Socioeconomic inequality in psychological distress among older adults in India: a decomposition analysis
}

\author{
Shobhit Srivastava', Naina Purkayastha², Himanshu Chaurasia ${ }^{3}$ and T. Muhammad ${ }^{1 *}$
}

\author{
Correction to: BMC Psychiatry 21, 179 (2021) \\ https://doi.org/10.1186/s12888-021-03192-4
}

Following the publication of the original article [1], an error was identified in the Results section of the Abstract. The updated section is given below and the changes have been highlighted in bold typeface.

Abstract:

Results

Older adults from the poorest wealth quintile, having no source of income, not working for the last one year period, suffering from multi-morbidity, disabled, with low activities of daily living and low instrumental activities of daily living and poor cognitive ability were suffering from high psychological distress in India. Further, factors such as religion, caste, education, living arrangements, and self-worth in the family were major contributors to the concentration of psychological distress in older adults from poor households (concentration index: -0.23$)$.

\section{Author details}

'International Institute for Population Sciences, Mumbai, Maharashtra 400088, India. ${ }^{2}$ Department of Statistics, Dibrugarh University, Dibrugarh, Assam, India. ${ }^{3}$ National Institute for Research in Reproductive Health, ICMR, Mumbai 400088, India.
The original article can be found online at https://doi.org/10.1186/s12888021-03192-4.

* Correspondence: muhammad@iips.net

${ }^{1}$ International Institute for Population Sciences, Mumbai, Maharashtra 400088, India

Full list of author information is available at the end of the article
Published online: 29 April 2021

\section{Reference}

1. Srivastava S, et al. Socioeconomic inequality in psychological distress among older adults in India: a decomposition analysis. BMC Psychiatry. 2021;21:179. https://doi.org/10.1186/s12888-021-03192-4.

\footnotetext{
Ready to submit your research? Choose BMC and benefit from:

- fast, convenient online submission

- thorough peer review by experienced researchers in your field

- rapid publication on acceptance

- support for research data, including large and complex data types

- gold Open Access which fosters wider collaboration and increased citations

- maximum visibility for your research: over $100 \mathrm{M}$ website views per year

At $\mathrm{BMC}$, research is always in progress.

Learn more biomedcentral.com/submissions

(c) The Author(s). 2021 Open Access This article is licensed under a Creative Commons Attribution 4.0 International License, which permits use, sharing, adaptation, distribution and reproduction in any medium or format, as long as you give appropriate credit to the original author(s) and the source, provide a link to the Creative Commons licence, and indicate if changes were made. The images or other third party material in this article are included in the article's Creative Commons licence, unless indicated otherwise in a credit line to the material. If material is not included in the article's Creative Commons licence and your intended use is not permitted by statutory regulation or exceeds the permitted use, you will need to obtain permission directly from the copyright holder. To view a copy of this licence, visit http://creativecommons.org/licenses/by/4.0/ The Creative Commons Public Domain Dedication waiver (http://creativecommons.org/publicdomain/zero/1.0/) applies to the data made available in this article, unless otherwise stated in a credit line to the data. 